\title{
“The Old Illusion of Belonging": Distinctive Style, Bad Faith and John Banville's The Sea
}

\author{
Monica Facchinello \\ University of York
}

Copyright (c) 2010 by Monica Facchinello. This text may be archived and redistributed both in electronic form and in hard copy, provided that the author and journal are properly cited and no fee is charged for access.

\begin{abstract}
John Banville's The Sea (2005) is not only a highly stylistic novel but also a novel about style. In The Sea Banville poses his obsessive question of identity and authenticity in relation to style as writing as well as writing as style and complicates the notion of style as traditionally understood in literary criticism. Contrary to most commentators' reading of the novel's style as merely manner of writing, in this essay I argue that Banville explores style as both manner of writing and manner of expression distinctive of its writer. The novel's rich language is one aspect among others of a distinctive style that the writer, John Banville, has forged during almost four decades of writing and in which he appears, in The Sea, uncannily at home. However, the identity obtained through style, like all other forms of identity previously investigated by Banville, is necessarily inauthentic. Any identity obtained through style, Banville believes, is obtained in what Sartre called "bad faith"; style betrays the writer's attempt to make himself what he is by playing at being someone he is not.
\end{abstract}

Key Words. Banville, style, Sartre, bad faith, home.

Resumen. The Sea (2005) de John Banville es no sólo una novela altamente estilística sino también una novela sobre estilo. En The Sea Banville plantea su obsesiva cuestión de identidad y autenticidad en relación con el estilo como escritura así como con la escritura como estilo y complica la noción de estilo tal como se entiende tradicionalmente en la crítica literaria. A diferencia de la lectura generalizada que considera el estilo de esta novela como simplemente un modo de escribir, en este trabajo se argumenta que Banville explora el estilo tanto como modo de escribir como un modo de expresión distintivo. El rico lenguaje de la novela es un aspecto más entre otros muchos de un estilo personal que el escritor, John Banville, ha forjado durante casi cuatro décadas de escritura y en el que, en The Sea, parece encontrarse asombrosamente a gusto. Sin embargo, la identidad que se obtiene mediante el estilo, tal como ocurre en todas las otras formas de identidad anteriormente investigadas por Banville, es necesariamente inauténtica. Banville cree que toda identidad conseguida mediante el estilo se consigue según lo que Sartre llamaba 'mala fe'; el estilo delata la tentativa por parte del escritor de hacerse lo que es mientras juega a ser quien no es.

Palabras clave. Banville, estilo, Sartre, mala fe, hogar.

John Banville's novels have been repeatedly hailed as the works of a master of language and a literary stylist and his thirteenth novel The Sea (2005) is no exception. One need only look to reviewers' emphasis on the quality of the novel's prose and its effects on the reader, in either praise or criticism, to see just how prominently style features in the text. In The

ISSN 1699-311X 
Times Literary Supplement, Robert Macfarlane lamented that "[t]he languorous ambience of [the narrator's] prose, indeed the entire structure of the novel, seems to exist only to permit Banville his exquisite scrimshaws of style" (Macfarlane 2005). In her review in The New York Times, Michiko Kakutani called Banville "a highly cerebral author who emphasizes style over story, linguistic pyrotechnics over felt emotion". She defined The Sea as a "pompously written book" and disapproved of its narrator's "grandiose language" - the protagonist, she wrote, "talks like someone with a Thesaurus constantly implanted in his head" (Katutani 2005). ${ }^{1}$ Others welcomed the book as a display of "the classical correctness of [Banville's] style" (Kenny 2005) and crowned the Irish novelist as "one of the finest prose stylists working in English today" (Tague 2005). "The book's strength lies in its language", we read in The Economist, "Banville's style affords the reader a voluptuous, unfashionable pleasure that grows with every re-reading of the book" (2005). Albeit different in their judgements, these commentators equally refer to style exclusively as a manner of writing, or, as the OED has it, "those features of literary composition which belong to form and expression rather than to the substance of the thought or matter expressed".

But style is not solely a manner of writing in The Sea. To the reader of Banville's earlier work, the writing of the novel's narrator Max Morden will not only appear exceptionally elaborate but also sound uncannily familiar. The text presents a fugue of familiar narrative peculiarities in Banville's oeuvre (the narrator's emphasis on the strange equivocations of language, for instance); it bristles with idiosyncratic expressions ("classless class", "strangury", "wind-worried day", to name just a few examples) and recurrent motives (the art historian, the homecoming journey, the obsession with the past, among others). Like Banville's previous texts, The Sea is saturated with references to the works of other writers as well as the novelist's own previous books. In The Sea, Banville explores and invests in style not only

1. See also Tibor Fischer's review of The Sea, "Wave after wave of vocabulary', and Sebastian Smee's “Sparks from sifted embers'. as a "manner of writing”, but also as a "manner of expression characteristic of a particular writer" and a "method or custom of performing actions [...], sanctioned by usage", as we read in two other definitions of style in the OED. By simultaneously exploring style as manner of writing and manner of expression distinctive of its writer, in The Sea Banville complicates the notion of style while setting out on a new exploratory journey into the slippery realms of identity, authenticity, home and belonging.

Since the anonymous historian of The Newton Letter (1982), all Banville's protagonists are men who have fabricated a new identity for themselves replacing the one bequeathed to them at birth. This operation leaves them effectively homeless. When the catastrophe, always impending, finally occurs and they are, in various ways, unmasked, they enter a moment of crisis. When men are in crisis, Banville explained in an interview, "they begin to search for solid ground to stand on, some place where they themselves, or some versions of themselves, will [...] be real" (2006). In previous novels, Banville has taken his protagonists to explore the birthplace (The Newton Letter, The Untouchable (1997), Eclipse), confessional narrative (The Book of Evidence (1989), The Untouchable), but also states of self-estrangement (Shroud (2002), Eclipse) and the Freudian uncanny (Ghosts (1993), Eclipse). In The Sea, in which, as Adam Phillips rightly states in his review of the novel, style is the "way the writer qualifies himself, or whatever he feels is in need of qualification” (2005), Banville sets out on a similar quest in relation to style as writing as well as writing as style. Style, in other words, features as an identity or a Heiddegerian home that the writer, John Banville, has fashioned for himself throughout his oeuvre. In the opening page of his "Letter to humanism", Martin Heidegger famously identified a link between language and being. "Language is the house of being. In its home man dwells", he wrote (1946). And in the 1951 lecture "Building Dwelling Thinking”, Heidegger went on to trace the interconnectedness between language, being and dwelling by exploring the etymology of the word bauen, to build: "The old High German word for building, buan, means to dwell [wohnen]. [...] Building as dwelling, that is, as being on the earth, however, remains for man's everyday experience that which is from the outset "habitual" - we inhabit it, as our 
language says so beautifully: it is the Gewohnte". In his 2000 novel Eclipse, Banville has his protagonist Alex Cleave voice a similar conviction. Mourning the untimely death of his daughter, a daughter he has long neglected, Cleave holds onto the hope that he will encounter her in the incoherent-looking pages of her papers: "[...] one day these pages will speak to me in that known voice, telling me all that I may or may not want to know" (211).

Banville's obsessive quest, however, is doomed. Sooner or later, all his protagonists come to the same conclusion, namely that there is no such home for them to be found. "There is no answer", Banville said, to "these questions of identity and authenticity": "[a]ll you can do is try to find new ways of posing the questions" (2006). The writer's quest for a home of belonging in style in The Sea is no exception. If Alex Cleave holds the Heideggerian conviction that there exists a fundamental link between language and being, his successor, and Max Morden's predecessor, Axel Vander is quoted to the effect that "every text conceals a shameful secret, the hidden understains left behind by the author in his necessarily bad faith” (349). Axel Vander, who has put on the identity of a dead friend of his in order to escape "[his] own individuality, the hereness of [his] self" (285), is probably Banville's best embodiment of Jean-Paul Sartre's notion of "bad faith". Bad faith, Sartre says, is a lie to oneself, the attempt at "hiding a displeasing truth or to show as truth a pleasing untruth", made possible, Sartre explains, by the fact that we are not "in-ourselves" what we are "for-ourselves" (1957). Bad faith can take different forms; here I consider the one which is most relevant to my argument, that is bad faith as a way of life or the putting on of a certain role as a way of responding to, in Sartre's words, "the constant obligation to make ourselves what we are" (1957). The French philosopher offers the example of the waiter in a café, a man who makes "the typical gestures" of the waiter in order to be one. But in having to play the role, to represent himself as a waiter, Sartre argues, this man confirms that he is not a waiter. If writing is a form of self-recreation, as we are asked to consider it in The Sea, it is, like all forms of self-recreation, a form of bad faith.

My purpose in this essay is to analyse Banville's stylistic investment in The Sea in relation to the writer's central questions of identity and authenticity. I will start by discussing Banville's narrative strategy of creating a narrator who lacks a distinctive personality. In teasing out the elements of Morden's selflessness, the analysis will identify some of the recurring features that are characteristic of Banville's writing. I then proceed by arguing that the narrator's indistinctiveness provides John Banville, the writer, with the ground on which to consolidate a distinctive self through style, and illustrating those traits that give Banville's writing its distinctiveness. In the light of the three definitions of style mentioned above, I interpret writing style as the summa of the features of literary composition that belong to both form and content, which characterise the writer on the ground of their recurrent presence throughout the entire oeuvre. The essay concludes by proposing that, while The Sea goes a great length to erect an identity through style, it also warns against attributing any authenticity to it and invites the reader to view the self thus constructed as a form of bad faith. This approach, I hope, will take us down a different track from those usually followed in reading the extraordinary verbal mannerisms of Banville's fiction, and in particular The Sea, while inviting us to take a fresh look at style, its constituents and potentials, especially in relation to identity.

Like The Untouchable and Eclipse, The Sea is cast in the form of a memoir written by a man in crisis. Following the recent death of his wife, Anna, Max Morden has returned to the setting of his childhood holidays in South-East Ireland, Ballyless. He has rented a room at "The Cedars", a lodging house run by Miss Vavasour whose only and permanent guest at present is Colonel Blunden from Belfast. Fifty years ago, Morden tells us, "the Cedars was a summer house, for rent by the fortnight or the month" (5) and one summer it was occupied by a mysterious and charming family: Connie and Carlo Grace, their twin children Chloe and Myles and their young governess Rose. Morden's narrative interweaves the memories of his summer holiday with the Graces, the recent ordeal of his wife's illness and death and his present stay at the Cedars.

The first thing we notice about Max Morden, as Phillips pointed out, is that he "has none of 
the grandiosity, swagger or amused selfobsession that drives the narrators of the earlier books. Max is an undistinguished man” (35). Like his predecessors and Banville himself, Morden feels uneasy about his lower-middleclass Catholic upbringing: "I will not deny it, I was always ashamed of my origins" (207). But unlike them, he is unable, or unwilling, to replace it with any solid-seeming fictional character, or mask of any kind such as the cultured murderer in The Book of Evidence, the quintessential English man in The Untouchable, the roles of the stage actor in Eclipse, and the dead friend's identity for the protagonist of Shroud. "From the earliest days", Morden confesses later in the narrative:

I wanted to be someone else. The injunction nosce te ipsum had an ashen taste on my tongue from the first time a teacher enjoined me to repeat it after him. I knew myself, all too well, and I did not like what I knew. Again, I must qualify. It was not what I was that I disliked, I mean the singular essential me - although I grant that even the notion of an essential, singular self is problematic - but the congeries of affects, inclinations, received ideas, class tics, that my birth and upbringing had bestowed on me in place of a personality. In place of, yes. I never had a personality, not in the way that others have, or think they have. I was always a distinct no-one, whose fiercest wish was to be an indistinct someone. I know what I mean (216).

With Morden, Banville creates a character whose characteristic feature is to have virtually no characterizing features.

Morden is denied three main elements of distinctiveness in the world of Banville's fiction: a name, a home and a profession. Morden records his mother's irritation at the discovery that Anna addresses him by a different name than his original one: "Why does she keep calling you Max? [...] Your name is not Max" (210). The name "Max" is not new in Banville's body of work; it features in two previous novels, and, contrary to Banville's typically evocative names such as "Gabriel", "Victor" and "Axel", Max is more an alias than a name. In The Book of Evidence we encounter Max Molynoaeux, who is less a character in his own right than a fictional disguise for Ireland's sixth Taoiseach Charles Haughey. In Shroud, the mysterious character and guardian-angel figure, Schaudeine, suggests that the narrator call him "Max" rather than his real name: "The name is Schaudeine," he says, "You might call me Max, if you wish" (254). In the Banville canon, "Max" identifies without characterising.

If the previous protagonists are repeatedly summoned back physically or imaginatively to their childhood homes, Banville wants us to imagine for Max a peripatetic life that left him effectively homeless. We are told that sometime after the memorial summer, his father abandoned the family and went to England; at that point, Max and his mother began to move from one rented room to the next. (It is significant that no mention is made of the place Morden lived in with his parents prior to their separation.) Morden's memory goes back to those rented rooms. "They were all alike", he writes, "[t]here was the armchair with the broken arm, the pock-marked lino on the floor, the squat black gas stove sullen in its corner and smelling of the previous lodger's fried dinners" (196-97). The homecoming dream that draws him back to Ballyless - "I was determinedly on my way somewhere, going home, it seemed, although I did not know what or where exactly home might be" (24) - is clearly the dream of a homeless man.

Morden's profession too is left strategically indefinite. The "sound of [his] typewriter", which his daughter remembers as a "comforting sound", suggests that he is a writer (69). And Max "writes about [art]", as Miss Vavasour confirms later in the narrative (150). Like the protagonists of Athena (1995) and The Untouchable, Morden is another art historian, an expert, this time, on the French painter Pierre Bonnard (1867-1947). He is currently engaged on a monograph on the painter, "a modest project", he calls it, "in which I have been mired for more years than I care to compute" and which does not aspire to make any original contribution to the public knowledge of Bonnard and his art (40). Unlike the work of Banville's previous art historians, his is done away from the public eye; Morden is not affiliated to any institutions or collaborating with anyone. In fact, applied to his modest though "professional" and "diligent" writing, even the word "work", he says, is inappropriate: it is "[t]he great ones [who] work" (41).

At this point Morden is less preoccupied with explaining his profession than with arguing for its indefinability; and the blame, as ever with Banville, is laid on language. Max 
laments the fact that for his "class" or "genus" of writers, "the middling men", "there is no word sufficiently modest that yet will be adequate to describe what we do and how we do it” (41). In other words, whatever it is, it is not the real thing.

If Morden is deprived of a name, a home and a profession, he certainly possesses a past: "The past", he pauses to say, "beats inside me as a second heart" (13). Most of his narrative is a journey into the past, "a place of womby warmth" of "shelter" and "cosiness" for Banville's bereaved narrator (60-61). Yet, a large part of the past Morden retreats into is quite obviously not his own. Although all Banville's books feature random tantalisingly autobiographical details, in none of them the correspondences between the narrator's fictional life and the author's appear as conspicuous and accurate as they do in The Sea, particularly in the narrator's account of his seaside childhood memories. Banville made no secret that in The Sea he was re-visiting the summer holidays of his childhood. And the article, "Lupins and moth-laden nights in Rosslare", which Banville wrote in 1989 as part of the writers-remembering-their-summerholidays-of-long-ago series for the Irish Times dispels any doubts we may be left with. The places - the Strand, Duggan's farm, the "corrugated-iron cinema" - and the rudimentary hut-life of Banville's memorial summers in Rosslare - his regular morning trips to buy the day's milk, his mother's cooking on a "Primus stove" and his father's night forays to bury the lavatory waste amid the lupins - enter Morden's narrative under virtually no disguise (see 47, 50, 208). In his An Essay Concerning Human Understanding, John Locke identified self with memory and argued that a person's identity extends to anything of her or his past that she or he can remember (1964). ${ }^{2}$ The Sea is not an

2. In a chapter dedicated to the understanding of identity and diversity, Locke writes: "Person stands for an intelligent being, that reasons and reflects, and can consider itself the same thing in different times and places; which it doth by Consciousness that is inseparable from thinking. By this every one is to himself what he calls Self, without considering whether that Self be continued in the same, or diverse substances. In this consists Personal Identity, or the sameness of a rational being: And so far as this consciousness extends backward to any autobiographical novel; Max Morden is not John Banville, but he is given Banville's humble origins and the memories of his childhood summer holidays, which form a major sub-story in the novel. In doing so, Banville again mocks the reader's attempts to view Max Morden as an individual character or self, and adds another trait to the protagonist's strategically indefinite persona.

Forged as an undistinguished character from the start, Morden, as Phillips pointed out, effectively loses personality and becomes the indistinct someone he wants to be in the ongoing writing. Direct and indirect references to the works of well-known artists and intellectuals have entered the texts of Banville's books since the first novel Nightspawn (1971); but in The Sea they are more visibly intertwined with Morden's story. At times, they compensate for what he lacks, at other times they act as metaphors; in both cases, they transform Morden's narrative into a chorus of others' voices. ${ }^{3}$ His account of his homecoming dream is a case in point:

A dream it was that drew me here. In it, I was walking along a country road, that was all. It was in winter, at dusk, or else it was a strange sort of dimly radiant night that there is only in dreams, and a wet snow falling. I was determinedly on my way somewhere, going home, it seemed, although I did not know what or where exactly home might be. [...] Something had broken down, a car, no, a bicycle, a boy's bicycle, for as well as being the age I am now I was a boy as well, a big awkward boy, yes, and on my way home, it must have been home, or somewhere that had been home, once, and that I would recognize again, when I got there. I had hours of walking to do but I did not mind that, for this was a journey of surpassing but inexplicable importance, one that I must make and was bound to complete. I was calm in myself, quite calm, and confident, too, despite not knowing rightly where I was going except that I was going home. [...] There was something the matter with my foot, the left one, I must have injured it, but long ago, for it was not painful, though at every step I had to throw awkwardly

past action or thought, so far reaches the identity of that person' (81).

3. For a broader analysis of intertextual references in The Sea, see Rüdiger Imhof's “The Sea: "Was't well done?”'. 
in a sort of half-circle, and this hindered me, not seriously but seriously enough. I felt compassion for myself, that is to say the dreamer that I was felt compassion for the self being dreamed, this poor lummox going along dauntlessly in the snow at fall of day with only the road ahead of him and no promise of homecoming (24-25).

The first echo we hear is from Elizabeth Bishop's poem "Questions of Travel” (1965): "think of the long trip home” (1. 13) and "“[...] Should we have stayed at home/ wherever that may be?'” (l. 66-67). ${ }^{4}$ The second allusion is to the protagonist of Banville's earlier novel Shroud, Axel Vander, and his account of his journey home. After the day-trip to Brussels, which saves him from the Nazi deportation, Vander goes home in the evening with the snow squealing under his boots and a sore shin (248). Both Morden's and Vander's accounts of a homecoming journey allude in turn to Molloy's journey to his mother's room in Beckett's novel. Molloy sets out on his "long journey home" despite his injured leg and the snow (170-71). Morden, who, as we are asked to believe, has never had a home, can only conjure up a picture for his dreamed self that is inspired by the homecoming thoughts and experiences of others.

Morden's writing more consistently draws on the works of two recognisable figures, Freud and Bonnard, both modernists ${ }^{5}$ for whom returning home is a primary concern. ("Morden", curiously, is an anagram of "modern"). If the content of Morden's childhood memories is mostly based on Banville's past, the narrative features all the ingredients of the Freud's 1909 essay Family Romances. Freud's essay traces the evolution of the neurotic child who at first strongly desires to become like his parents; but as he "develops intellectually, he cannot help gradually getting to know the category his

4. The two lines, ““[...] Should we have stayed at home/ wherever that may be?"', which conclude the poem, are quoted in the opening page of Banville's idiosyncratic portrait of Prague, Prague Pictures (2003).

5. According to Jörg Zutter, “[Bonnard's] interpretations of reality are without precedent in early modernism, keeping the viewer in a new kind of vertigo' (38). parents belong to", Freud writes. "He becomes acquainted with other parents, compares them with his own, and so becomes entitled to doubt the incomparable and unique status he once attributed to them" (Freud 2003). The encounter with the Graces, which opens the narrative of the memorial summer, also coincides with Max's realisation at the age of ten of his parents' humble social category. The narrator's family, like Banville's, spent their holidays in a wooden chalet in the Field. And in the "social structure of [the] summer world" at Ballyless, he tells us, the chalet tenants were at the bottom:

The few families who owned holiday homes were at the top, then came those who could afford to put up at hotels - the Beach was more desirable than the Golf - then there were the house renters, and then us (108-109).

Morden remembers feeling embarrassed by his parents in the presence of the Graces, and desiring to rid himself of them. "Had it been in my power", he writes, "I would have cancelled my shaming parents on the spot, would have popped them like bubbles of sea spray, my fat little bare-faced mother and my father whose body might have been made of lard" (37). In Freud's essay, the child experiences feelings of envy, which he expresses in a "fantasy that replaces both parents by others who are grander" (2003). And the Graces, as the name suggests, ${ }^{6}$ are Morden's grander parents; they rent a "proper house", are from "the city" (78), have a big car with a "touring map of France, much used” (6) and enjoy a stylish life (11112).

In his own family romance, Morden goes through nearly all the stages spelt out in Freud's story. His "first (asexual) stage" (2003) begins as he falls in love with Mrs Grace (32); it is a thrust of Oedipal love for a mother not his own. He becomes prey to what Freud calls the "peculiar imaginative activity" of the neurotic child, or "the familiar phenomenon of daydreaming" (2003), the two

6. 'Grace' reminds us of Joyce's short story "Grace' in Dubliners. And in a note to the title of Joyce's short story, Terence Brown points out: “[i]n Roman Catholic theology, grace is a supernatural gift freely given by God to rational creatures to enable them to obtain eternal life. Grace in less specific English usage can refer to personal style and graciousness of manner' (294). 
main aims of which are erotic and ambitious. And Max too starts inventing ambitious and erotic dramas, in which he would rescue Mrs Grace "from great and general catastrophe, a shipwreck or a devastating storm, and sequestered her for safety in a cave" (73). Here, he continues, "she leaned her head on my arm and touched my face in gratitude and sighed, and so we went to sleep together, she and I, [...]" (73). In these fantasies, Mrs Grace's natural children and husband are conveniently removed from the scene and she is transformed at once into his imaginary lover and mother. Max's romance soon enters "the second [sexual] stage" (Uncanny 39), in which the child's fancies become more explicitly erotic. "Knowledge of sexual processes", Freud writes, "gives rise to a tendency on the part of the child to picture to himself various erotic situations and relationships” (2003). Morden remembers how the mere thought of naked flesh "gutted [his] inexperienced but already overheating imagination with reveries of love and love's transgressions" (74) in spite of his ignorance of the mechanics of the act. When one night Max almost stumbles over a couple making love - "the man's flanks rhythmically busy in the upright wishbone of the woman's lifted, wide-flung legs" - his sexual awakening is complete: "So this", he remembers thinking or it being thought for him, "so this is what they do" (75).

Morden recalls setting out to make acquaintance with the twins in order to increase his chances of being in the vicinity of Mrs Grace in the hope of catching something of her, the more forbidden the more desirable (79). However, closer to the twins, Max finds himself gradually falling in love with Chloe. The transference of the boy's affections from Mrs Grace to her daughter Chloe acts as a Freudian "variant": the course of the story, Freud writes, can be diverted by "any other special interest" (2003). Like the Freudian "fantasist", Max conveniently re-establishes the blood-difference between himself and the twins, thus allowing himself to be Chloe's lover. Morden's family romance concludes in tragedy, with the twins' death by drowning and Max's arrival at the Cedars with the sad news for their parents. At this point the boy momentarily becomes the Graces' only child "and so we stood in stillness, we three, at the end" (247) - but also loses them for ever. The conspicuous correspondences with Freud's story add another foreign element to Morden's account of childhood memories, already not his own, thus effectively demolishing the very foundation of the self that childhood is said to be.

If Freud's Family Romances shapes the narrative of Morden's juvenile memories, Bonnard's paintings act as a lens through which past and present scenes are seen. Bonnard is best known as a painter of intimate, domestic interiors, particularly attracted to spaces within the house: the dining room, the bedroom and the bathroom. In the 1890s, as Nicholas Watkins writes in his monograph on the artist, Bonnard was mainly painting the rooms of his childhood house, Le Clos, later replaced by Le Bosquet, the house he shared with his wife Marthe (56). For Bonnard, rooms were "analogues of human experience, they contained memories and told stories about their inhabitants' lives and status” (Bonnard 52). For him, as for Proust, memories of time past "could only be recaptured through being activated in the present" (Watkins 1994: 20). Morden too returns to the Cedars in the hope of activating his childhood memories. But the Cedars has retained "hardly anything of the past, of the part of the past that I knew there"; its many lodgers have worn away all traces of the Graces (39). Furthermore, the Cedars never was a home: it has always been "a lodging house, after all”, Morden tells us (39). In Morden's present recollections of his time past at the Cedars, the descriptions of the house contain details he has taken, consciously or not, from the rooms of Bonnard's homes. These are, for example, "those vestigial flowers" - "sweet pea? all at once I seem to see sweet pea" (89) - on the table of the living room that Morden remembers noticing on his first visit to the Cedars (89). And Sweetpeas is the title of one of Bonnard's 1912 paintings, featuring a vase of sweet pea on a table. Likewise, the small black dog that the narrator no sooner adds to his image of the kitchen than wonders whose it may have been (90) is a recurring detail in Bonnard's paintings, see for example Woman and Dog (1891), The Bathroom (1932), Nude in the Bath and Small Dog (1941-6). Like the intertextual allusions in the homecoming dream, the presence of details from Bonnard's interiors in Morden's pictures of the Cedars signal an attempt to compensate 
for his homelessness, while at the same time it acts as a reminder for us of Morden's peculiar condition. If Morden achieves any sense of homeness for the Cedars, this is at the expense of his selfhood, as those added details eloquently point to the home and self of another.

Another reflex of the French painter's art is visible in Morden's pictures of other people and himself in a more recent past and the present. To Max's mind steeped in the painter's early Japonisme, ${ }^{7}$ Miss Vavasour's hair-style is "suggestive, wholly inappropriately, of the geisha-house," and "the kimono-like belted silk dressing-gown that she wears of a morning, the silk printed with a motif of brightly coloured birds and bamboo fronds" continues the "Japanese note" (38-39). Morden's recollection of his daughter Claire, in her early teens, in the bathroom "naked save for a towel wrapped tightly turban-fashion around her head [...] in a fall of calm light” (62) echoes Bonnard's numerous portraits of Marthe at her toilet holding a towel and exposing her naked body to the light. And in the "long, grim gander" Morden takes at himself "in the bathroom mirror" (127) we, and the narrator himself, are reminded of Bonnard's later self-portraits. As John Kenny has pointed out in his study of ekphrasis in Banville's work, paintings feature prominently in all his novels (2006). Yet, I suggest, the use that narrators make of paintings in their narratives significantly differs. Morden's predecessors refer to or recreate specific paintings mostly in the attempt to increase vividness by generating realistic visual accounts of this character or that landscape. Morden instead uses Bonnard's pictorial human figures and settings as models for his settings, human figures and even for himself. On these occasions, he appears as a narrator sceptical of his own narrative abilities. His comment that Bonnard would have done a better job at representing the "silky, silvery grey" of the weathered wood of the shed at the Cedars than he can do - Bonnard, he writes, "would have caught that texture exactly, the quiet sheen and shimmer of it" (43) - certainly

7. Watkins points out that the two main influences that shaped Bonnard's early style were Gauguin and Japanese art (Bonnard 21). suggests so. Morden's lack of confidence in his descriptive and inventive competences completes the portrait of indistinctiveness that Banville has reserved for his 2005 narrator Max Morden.

In the writing in which the writerly protagonist Max Morden loses self, the writer John Banville constructs one for himself. This we may call the writer self, one other than the self, or selves, of the man, as Banville has pointed out in an interview: "The John Banville who writes about life, is not the John Banville who lives. They are two entirely separate beings" (2006). For Banville, the act of writing enacts a transformation from the self of the man who lives into another self (2006). The writer self is a mask, not unlike his protagonists' masks, that Banville has forged for himself throughout three and a half decades of writing, and it is at its most distinct in The Sea, a book that in many ways concludes a long series of novels that began in 1973 with Birchwood.

Phillips, the only reviewer to see The Sea's style as a form of self-qualification ("style is the way the writer qualifies himself"), explains that "to qualify something or someone is at once to legitimate it and to go on explaining it”(2005). The recurring features, tics and tropes in The Sea, which generate the sense of uncanny familiarity in the writing, perform precisely these two functions. They sanction the writer's distinctive voice and go on clarifying the image of the kind of writer John Banville has become known to be and, in large part, he has aspired to become since the beginning of his artistic career. In what follows, I will consider Banville's obsession with language, the poetic quality of his prose, and intertextuality.

In his review of The Sea, Fintan O'Toole is right to refer to the novel's language as "a physical object" (62). It is something the narrator openly researches: "Lupinus, a genus of the Papilonaceae, I have just looked it up" (49-50); among the tools at his disposal, he mentions the "Black's Medical Dictionary" and "Roget's Thesaurus" (129, 130). Language is dexterously re-arranged in self-conscious patterns, as in "landlubbered" seafarer (5), "hare-eyed panic" (16), “classless class" (208), to name only a few examples. It is a tool 
subject to time - "Plimsoll," Max notices, "Now, there is a word one does not hear any more, or rarely, very rarely" (11) - and a limited tool - "[...] there is no word sufficiently modest that yet will be adequate to describe what we do" (41). From the start of his career, Banville has situated language, or, as he called it, "the problem with language", at the forefront in the writer's work. The writer, or the literary artist, for Banville, is constantly faced with, on the one hand, the obligation to capture the "thereness of the world" in words and, on the other, a profound distrust of language. This predicament, Banville goes on to say, weighs particularly on the Irish writer writing in what he calls "Hiberno-English", a language "at once wonderfully expressive and [...] poetically imprecise" (1981). There is more to Morden's "linguistic pyrotechnics" than mere "scrimshaws of style". The narrative's emphasis on the equivocations of language, its peculiarities, potentials and limitations confirms a commitment to language that is central to Banville's writing and that distinguishes Banville among his contemporaries writing in English.

The obligation to capture the "thereness of the world" on the page is most visible in those moments when the prose in The Sea verges on "poetry". The achievement of an overtly poetic tone is a feature that has become increasingly prominent in Banville's writing, especially since The Newton Letter. It is mostly in the descriptions of natural landscapes and characters that the writing achieves the sensuous beauty and vividness of poetry. In The Sea, take, for example, the image of stormy weather that the narrator recollects from his time in the house, also by the sea, which he shared with Anna: “[...] the autumn gales groaned in the chimneys and the waves were coming over the sea wall in washes of boiling white spume" (93). The rhythm of three pentameters, with the second and third lines linked by an enjambment, is immediately audible, and alliterations, such as "gales/groaned", "waves/were" and "wall/washes", accentuate the rhythm. Anthropomorphisms and similes, two other rhetorical figures more common to poetry than prose, also feature frequently in the narrative in The Sea and generate vivid visual images and powerful physical sensations. The "autumn gales", for example, "groaned". Morden remembers imagining "little waves lapping hungrily at [Chloe's] heels" (243), and describes nature's disregard for human life as "just another of the great world's shrugs of indifference" (263). Descriptive vividness is similarly obtained by ascribing non-human attributes to human body parts, as for instance in: "the hairline cracks in the porcelain backs of [Chloe's] knees” (167). Similar poetic features punctuate the texts of Banville's previous novels, in particular The Newton Letter and Ghosts.

The frequent presence of these and other rhetorical figures has encouraged readers and critics to refer to Banville's prose as poetic, thus sanctioning a second element of distinctiveness in the writer's voice. However, like the obsession with language, this element is informed by and points to another important feature in the making of the Banville artistic persona. One of Banville's early ambitions was to write novels that aspired to the condition of art, and more specifically poetry. While he refuses the definition of "poetic prose" for his writing, he nonetheless is keen to associate it to a singular, indefinable quality that in many ways takes his prose - although Banville would not call it prose either - close to poetry. In an interview Banville explained:

The kind of writing that I do springs from an intensity of concentration that makes the words flare into what is neither prose nor poetry but something else. I don't like the definition "poetic prose," which is the worst kind of prose, I mean "poetic" in the sense of prettiness, floweriness, over-sensitiveness. But when prose is pressed on strongly enough it begins as it were to blush, blood begins to flow, and that's what makes it something that acts on the reader like poetry. It isn't poetry, but it's not prose either ("Reinventing” 6).

This type of prose, Banville said, is also to be found in Beckett's work, but not in Joyce's. Beckett, he went on to explain, "is constantly being carried by the beauty of not just the words but of the thought informing the words. Joyce doesn't speculate in prose, he just writes prose”. Whether Banville's view of the two writers' prose is valid or not, is not for me to say here. Rather, it is interesting to notice that, in his assessment of Joyce and Beckett's writing, Banville treats the prose style as indicative of important elements of the writer's selves; 
in Beckett's writing he sees a speculative writer, one "constantly carried away by the beauty of" language. And Banville, who has often acknowledged his profound indebtedness to Beckett, wishes that his readers may see the same type of writer in his writing.

As I have shown, the dense web of references to the works of others in The Sea further blurs the already murky image of the protagonist's staggering self. At the same time, it voices Banville's long-time indebtedness to the European and American literary and artistic traditions and his early urge to be considered as a European writer as opposed to an Irish writer. In addition to the works of Freud, Bonnard, Bishop and Beckett, other allusions we encounter throughout the narrative are to texts by Henry James, Joyce and Nabokov among others, which have consistently informed Banville's writing throughout his career.

Finally, Morder's narrative gathers almost all the main motifs and tropes that have entered the ten novels that separate Birchwood from The Sea: the man in crisis, the Big House, betrayal, class divisions, the distrust of memory and the uneasiness with naming Irish places ("the town, I shall call it Ballymore," Morden writes, "this village is Ballyless, ridiculously, perhaps, but I do not care” (9)), among others. In a typical Banvillean fashion, characters' names are highly evocative. The doctor who diagnoses Anna's incurable cancer, for instance, is called "Mr Todd", a name that, like Morden, the German for "to kill", appropriately suggests death. The family "Grace", also referred to as "the Graces" is another case in point: the name combines at least three different domains, the three Graces of the Greek tradition, and the notion of Grace in art and in Christian theology. Furthermore, characters' names - Charlie, Weiss, Anna, Rose, Max and Morden - return from Banville's previous books, and they do so in a number too high for it to be a coincidence. While they certainly contribute to the image of the writer self, these repetitive traits are more likely to be perceived by the faithful reader of Banville in the form of tics and habits, "customs sanctioned by usage", which generate that element of familiarity we end up calling the writer's distinct voice.
In the "text" of The Sea, Banville, in Adorno's terms, "sets up house". "For a man who no longer has a homeland", as Banville the writer has defined himself to be, "writing becomes a place to live" (Adorno 1974), a place of belonging, a home, like the home of origin to which all Banville's protagonists return in the hope of finding again their lost selves. Yet, no sooner does the narrative construct such a dwelling place, than its validity is called into question. Banville exposes the limits of style as house of being by setting up a parallel situation in Morden's narrative in which style is at once revealing and deceptive.

A highly stylistic novel, The Sea is also a novel about style. Max Morden is characterised, for one thing, by a strong attraction to habits and styles of other living beings, human but also animal. Only a few pages into the narrative, for instance, we are told of Miss Vavasour's preferring to call the living room, "in landladyese, the lounge" (4). Later Morden notices the repetitive movements of a robin in the garden and pauses to comment: "it favours doing things by threes, hopping from a top twig to a lower and then a lower again where it stops and whistles thrice its sharp, assertive note. All creatures have their habits” (42). By the end of the narrative, almost each of the novel's characters is attributed at least one behavioural trait. Morden not only invites us to notice such repetitive traits, he prompts us to see them as distinctive of the individual or the self they belong to. Driving Morden's watchfulness, we read, is "curiosity, the simple passion to know something of the secrets of other, alien lives” (158). At times, Morden's references to other characters' repetitive behaviours and habits identify something generic. The "expression of hostile enquiry" on Myles's face at their first encounter, for instance, "was the way we all looked at each other," Morden comments, "we children, on first encounter" (11). Mr Todd's hair is "oiled in the style of an earlier time" (15). And Mrs Grace smokes "in the way that women did in those days, one arm folded across her midriff and the elbow of the other cupped in a palm" (92). Other references instead individuate. In Max's picture of his first sight of Anna, for example, she is standing, "talking to another woman, in that way she had, at once intent and 
remote, dreamily twisting a lock of hair around a finger" (100, emphasis added). He remembers Chloe's smiling at him "her cat's thin gloating smile" (115, emphasis added) after being told off by her mother. And recounting a recent meeting with the photographer and Anna's friend, Serge, Max describes him flapping a hand "limply up and down in his studied Mitteleuropan way" (179, emphasis added). Other people's styles, like writing style in The Sea, convey for each person a sense of distinctiveness and a solidseeming character that the narrator himself lacks. (It is no coincidence that the only tic Morden detects for himself is a "thin, wintry whistling through the front teeth" he has begun to do recently, which, he says, he has inherited from his father (8).)

Towards the end of the narrative and of Morden's stay at the Cedars, however, we are told of a bewildering change of habit in the Colonel, unexpectedly and inexplicably wearing his weekend yellow waistcoat on a weekday. Morden immediately finds himself doubting his previous assumptions about the Colonel's identity: "I shall never know, now," Morden comments, "if he is really an old army man or an impostor" (262). Like Sartre's waiter, the Colonel is charged with playing at being someone he never was. In other words, he is caught acting in bad faith, thus exposing the performative nature, and essential inauthenticity, of all those behavioural and physical traits, indeed the style, through which he realized his "condition", as Sartre calls it, as an army man. Similarly, earlier in the text, Morden registers an instance in which behaviours and gestures, performed by others this time, persuasively make him someone he is not. He recalls the people attending upon him immediately after Anna's death: "With what tenderness they gazed at me across the grave-mouth, and how gently yet firmly they took my arm when the ceremony was done [...]. I felt I should stop and hold up a hand and tell these people that really, I did not deserve their reverence [...] that I had been a bystander, a bit-player, while Anna did the dying” (203-204). Again Morden stresses the falsity of the condition thus realized by using the term "impostor" (203). By the same token, any of the other solid-seeming personalities in Morden's narrative, and above all the writer self, have an element of inauthenticity inherent in their distinctiveness: to the degree that their beings or selves are distinctive, they are also inauthentic.

The fact that style offers no more satisfactory solution to the questions of identity and authenticity than previously researched realms in Banville's oeuvre is not surprising. Banville, after all, has always been more concerned with proving the insolubility of such questions, with confirming that belonging is an illusion and authenticity nowhere to be found. The narrative in The Sea raises a different and more fundamental question: the question as to what writing style really is. It urges us to consider style as not only "manner of writing", as so many readers and critics of The Sea have done, but also "method and custom of performing actions [...] sanctioned by usage" and "expression characteristic of a certain writer". Banville has proved that, inauthentic as it may be, identity can be forged in style. This interpretation of style will shed new light on the work of other contemporary novelists renowned for investing in style such as Kazuo Ishiguro and Claire Messud, both of whom share Banville's concern with the slippery notion of identity. Paul Auster's fiction, which increasingly delights in intratextuality, would benefit from a reading of style along similar lines.

\section{Works Cited}

Adorno, Theodor. 1974. Minima Moralia: Reflections from Damaged Life. Trans. E.F.N. Jephcott. London: Verso.

Annan, Gabriele. 2006. “Suddenly, Last Summer.” Rev. of The Sea by John Banville. The New York Review of Books. 9 March. 33.

Anonymous. 2005. “From the deep.” Review of The Sea by John Banville. The Economist. 15 October. 88.

Banville, John. 1981. “A Talk”. Irish Literary Supplement. XI 1. 13-17. 2000. Eclipse. London: Picador.

. 1989. “Lupins and moth-laden nights in Rosslare.” Irish Times. 18 July. 11.

1993. Nightspawn. 1971. Oldcastle: Gallery. 
1979. “ 'Novelists on the Novel.' Interview with John Banville and Francis Stuart.” Conducted by Ronan Sheehan. Crane Bag. 3 1. 76-84.

1984. "Place Names: The Place”. Ireland and the Arts. Ed. Tim Pat Coogan. A Literary Review Special Issue. London. 62-65.

2003. Prague Pictures. London: Bloomsbury.

2006. “ 'Re-inventing Ireland in Art': Interview with John Banville.” Nae 17. 3-7.

2002. Shroud. London. Picador.

2005. The Sea. London: Picador.

Beckett, Samuel. Molloy. 1976. London: Calder.

Bishop, Elizabeth. 1969. The Complete Poems. New York: Farrar.

Brown, Terence. 1992. “Notes.” Dubliners by James Joyce. London: Penguin. 237-317.

Fischer, Tibor. 2005. "Wave after wave of vocabulary." Sunday Telegraph. 5 June http://infoweb.newsbank.com/iw-search/we/InfoWeb [Retrieved 30 Jan. 2006].

Freud, Sigmund. 1971. The Complete Introductory Lectures on Psychoanalysis. Trans. James Strachey. London: George Allen.

2003. The Uncanny. London: Penguin.

Grylls, David. 2005. “Not waving but drowning.” Sunday Times. 12 June.

Heidegger, Martin. Basic Writings. Ed. David Farrell Krell. London: Routledge, 1977.

Imhof, Rüdiger. 2006. “The Sea: ‘Was’t well done?’” Irish University Review: Special Issue John Banville. 361. 165-81.

Kakutani, Michiko. 2005. “A Wordy Widower with a Past.” Rev. of The Sea by John Banville. New York Times. 1 November http://www.completereview.com/reviews/banvillej/Sea.htm [Retrieved 30 January 2006].

Kenny, John. 2006. “Well Said Well Seen: The Pictorial Paradigm in John Banville’s Fiction”. Irish University Review. 36 1. 52-67.

2005. "What lies beneath." Rev. of The Sea by John Banville. Irish Times, 28 May http://www.ireland.com/newspaper/weekend/2005/0528/3528305700WKBK28BANVILLE.html [Retrieved 12 June 2005].

Locke, John. 1690. 1964. Essay on Human Understanding. Book II. London: Dent.

Macfarlane, Robert. 2005. “The world at arm’s length.” Rev. of The Sea by John Banville. Times Literary Supplement. 3 June. 19.

O’Toole, Fintan. 2005. “The Clank of Irish Bones.” Rev. of The Sea by John Banville. Prospect. June. 62.

Phillips, Adam. 2005. “My Own Ghost.” Rev. of The Sea by John Banville. London Review of Books. 4 August. 35-36.

Sartre, Jean-Paul. 1957. Being and Nothingness: An Essay on Phenomenological Ontology. Trans. Hazel E. Barnes. London: Methuen.

Smee, Sebastian. 2005. “Sparks from sifted embers.” Spectator. 7 May. 49.

Tague, John. 2005. Rev. of The Sea, by John Banville. Independent on Sunday. 4 September http://www.complete-review.com/reviews/banvillej/sea.htm [Retrieved 30 January 2006].

Watkins, Nicholas. 1994. Bonnard. London: BCA. 1998. Bonnard: Colour and Light. London: Tate Gallery Publishing.

Zutter, Jörg, 2003. ed. Pierre Bonnard: Observing Nature. Camberra: National Gallery of Australia.

Received 30 March 2009 Revised version accepted 25 May 2009

Monica Facchinello holds a PhD in English Literature from the University of York. Her interests are in contemporary Irish writing, with a focus on questions of identity and home. She has published articles on John Banville's novels and is currently working on the monograph John Banville and Ireland: Fictions of Home. 